\title{
Toponimi Nama Tempat Berbahasa Sunda di Kabupaten Banyumas
}

\author{
Cece Sobarna, Gugun Gunardi, Wahya \\ Program Studi Ilmu-Ilmu Sastra, \\ Fakultas Ilmu Budaya, Universitas Padjadjaran \\ Jalan Raya Ir. Soekarno km. 21, Jatinangor, Sumedang 45363 \\ Email: cece@unpad.ac.id, cecesobarna@yahoo.com
}

\begin{abstract}
The continuous changes of society have brought some impacts to the name of a place. Even though it is only a name, it actually deals with the cultural perspective of the surrounding communities. Currently, toponym becomes important for society as a part of identity formation processes including for the Sundanese. Beside spoken in West Java and Banten, Sundanese language is also spoken by Central Java communities who live in western areas such as Cilacap, Brebes, and Banyumas regencies. In Cilacap and Brebes regencies, Sundanese language is still an effective language for daily communication. However, in Banyumas regency, this language undergo changes. In fact, the Sundanese language in Banyumas is a quite unique since the archaic words such as pineuh (sleeping) and teoh (below) are still found. This area still keeps its oral tradition such as the story about the history of the place names. The study of the place name is an effort to strengthen an identity as the place name can be understood as a symbol rooted on the history of the place in its local culture. This tradition contributes toward a sustainability of the place name along with their cultural values.
\end{abstract}

Keywords: place names, local wisdom, identity

\begin{abstract}
ABSTRAK
Perubahan masyarakat yang terus-menerus berpengaruh pada perubahan penamaaan tempat di suatu daerah. Tidak hanya sekadar nama, dalam penamaan sebuah tempat terkandung pandangan masyarakat pemiliknya. Saat ini, toponimi menjadi bagian penting dalam kehidupan manusia sebagai bagian dari proses pembentukan identitas. Selain di wilayah Jawa Barat dan Banten, bahasa Sunda digunakan pula oleh sebagian masyarakat Jawa Tengah yang berada di bagian barat, seperti Kabupaten Cilacap, Brebes, dan Banyumas. Di wilayah Kabupaten Cilacap dan Brebes bahasa Sunda sampai sekarang masih digunakan. Namun, di wilayah Kabupaten Banyumas, bahasa Sunda mengalami penyusutan. Padahal, bahasa Sunda di wilayah tersebut cukup menarik, yakni masih ditemukan katakata arkais, seperti pineuh (tidur) dan teoh (bawah). Wilayah ini juga masih menyimpan banyak tradisi lisan, di antaranya adalah ihwal cerita terjadinya nama tempat. Pengkajian nama tempat merupakan sebuah upaya yang strategis dalam rangka penguatan jati diri bangsa karena nama tempat dapat dipahami sebagai tanda yang mengacu pada cerita dan sejarah yang berakar pada budaya lokal. Tradisi ini berkontribusi terhadap kelanggengan nama berikut nilai-nilai budaya di dalamnya.
\end{abstract}

Kata kunci: nama tempat, kearifan lokal, jati diri 


\section{PENDAHULUAN}

Potensi yang dimiliki oleh bangsa ini tidak terbatas pada apa yang ada saat ini, tetapi juga dapat berupa sisa-sisa dari budaya masa silam. Salah satu budaya masa silam itu adalah budaya Sunda yang ada di Jawa Tengah. Sebagaimana kita pahami bersama, budaya mencakup di dalamnya adalah bahasa. Sisa budaya Sunda dalam bentuk bahasa di Jawa Tengah masih dapat dilacak, baik pada individu masyarakat maupun pada penamaan daerah. Hal ini tentu menarik untuk dikaji mengingat eksistensi sebuah (suku) bangsa tidak terlepas dari sebuah proses perjalanan budaya (sejarah).

Di samping itu, wilayah budaya tidak selalu identik dengan wilayah administrasi, sebagaimana terjadi pada Jawa Barat dan Jawa Tengah. Sekalipun dua provinsi ini dipisahkan oleh kabupaten masingmasing, tetapi kenyataannya, baik nama tempat maupun budayanya, tidak ketat memisahkan antara budaya (bahasa) Sunda dan Jawa. Hal ini terjadi mengingat di wilayah Jawa Tengah banyak ditemukan nama tempat yang berasal dari bahasa Sunda. Begitu pula di Jawa Barat bagian timur banyak ditemukan nama tempat berbahasa Jawa. Misalnya, salah satu kecamatan di Kabupaten Pangandaran bernama Kalipucang. Beragam penafsiran muncul bahwa kata itu berasal dari bahasa Sunda peucang atau 'kancil'. Padahal berdasarkan informasi dari masyarakat, kata itu berasal dari bahasa Jawa pucang 'pinang'. Hal itu dapat dipahami karena masyarakat Kalipucang merupakan masyarakat campuran Jawa-Sunda. Di samping itu, kata kali atau 'sungai' berasal dari bahasa Jawa. Dengan demikian, Kalipucang dipahami sebagai tempat yang dulunya merupakan sungai yang di pinggirnya banyak tumbuh pohon pinang. Hal seperti inilah yang menarik untuk dikaji, mengapa terjadi seperti itu, ada peristiwa budaya apa di daerah tersebut. Begitu pula nama berbahasa Sunda di daerah Jawa Tengah bagian barat, telu- suran atas nama-nama tempat (toponimi) dapat menguak peristiwa budaya/sejarah masa silam.

Banyak upaya yang dapat dilakukan dalam melestarikan budaya daerah. Hal ini penting mengingat budaya daerah merupakan akar dari budaya nasional. Upaya pelestarian sejalan dengan penjelasan Undang-Undang Dasar 1945 yang berhubungan dengan Bab XV, pasal 36. Pasal tersebut menyatakan bahwa bahasa-bahasa daerah yang masih dipakai sebagai alat perhubungan yang hidup dan dibina oleh negara karena bahasa-bahasa itu adalah bagian dari kebudayaan yang masih hidup (Halim, 1976). Penjelasan itu secara tersirat mengandung dua persoalan pokok, yaitu (1) pengakuan terhadap bahasa Indonesia sebagai bahasa nasional dan bahasa resmi negara, dan (2) pemeliharaan yang sekaligus juga berarti pembinaan, pengembangan, dan pemeliharaan bahasa-bahasa daerah.

Bahasa Sunda merupakan bahasa daerah yang jumlah pemakainya cukup banyak, yakni terbesar kedua setelah bahasa Jawa. Wilayah pemakaian bahasa Sunda hampir meliputi seluruh wilayah daerah Provinsi Jawa Barat, Banten, dan bahkan terdapat juga di wilayah Provinsi Jawa Tengah. Bahasa Sunda terdiri atas beberapa dialek, di antaranya bahasa Sunda dialek Banten, Priangan, Ciamis, Cirebon, dll. Sejalan dengan isi penjelasan pasal 36, Bab XV, UndangUndang Dasar 1945 di atas, pemakaian bahasa Sunda yang baik bukan saja berguna bagi pengembangan serta pertumbuhan bahasa daerah itu sendiri, melainkan juga merupakan upaya yang tepat untuk membantu pembinaan dan pengembangan bahasa nasional, bahasa Indonesia.

\section{Kajian Teori Toponimi}

Secara harfiah toponimi berarti nama tempat. Dalam teori linguistik, toponimi dapat dilihat sebagai 'tanda' yang terjadi tidak secara arbitrer. Radding \& Western 
(2010: 399) mengemukakan bahwa konteks di antara kata-kata yang arbitrer di dalam suatu bahasa tertentu dan dalam situasi tertentu tidaklah artbitrer. Kita mencintai dan memedulikan suatu nama tertentu karena nama tersebut mengandung lapisan makna. Lapisan makna tersebut berasal dari budaya tempat itu berada dan melampaui kata-kata sehari-hari atau biasa. Dengan demikian, toponimi harus dapat dipahami sebagai sebentuk 'tanda'.

Nama tempat merupakan suatu bentuk cerita dan sejarah yang secara tradisi diturunkan di antaranya melalui folklor (Danandjaja, 2004). Bentuk cerita tersebut menelusuri proses penamaan (naming) berbagai hal, seperti jalan, orang, makanan, buah-buahan, tumbuh-tumbuhan, dan tempat. Dalam kajian folklor, kajian mengenai nama tersebut dinamakan onomastika (onomastics).

Ahli lain, Ayatrohaedi dalam Sudaryat dkk. (2005), mengemukakan bahwa pengetahuan mengenai nama lazim disebut onomastika. Ilmu ini dibagi atas dua cabang, yakni pertama, antroponim, yaitu pengetahuan yang mengkaji riwayat atau asal-usul nama orang atau yang diorangkan; kedua, toponimi, yaitu pengetahuan yang mengkaji riwayat atau asal usul nama tempat. Selain onomastika, Nida dalam Sudaryat dkk. (2005), menyebutkan penamaan tempat atau toponimi juga termasuk ke dalam teori penamaan (naming theory). Lebih jauh, dengan mengutip Nida, Sudaryat menyebutkan bahwa proses penamaan berkaitan dengan acuannya. Penamaan bersifat konvensional dan arbitrer. Bersifat konvensional karena disusun berdasarkan kebiasaan masyarakat pemakainya, sedangkan bersifat arbitrer karena tercipta berdasarkan kemauan masyarakatnya.

Rais dkk. (2008: 4-5) mempertegas perihal toponim dan toponimi. Kata toponim diserap dari bahasa Inggris, toponym. Kata tersebut merupakan perpaduan dari kata topos 'tempat, permukaan' dan nym (onyma) 'nama'. Dengan demikian, dapat dipahami bahwa toponim sebagai nama tempat atau nama rupa bumi. Ilmu yang mempelajari toponim itu sendiri pada umumnya dan nama geografis khususnya adalah toponimi.

\section{Masyarakat Sunda dan Orientasi terhadap Lingkungan}

Manusia dan lingkungan senantiasa berjalan secara selaras. Dalam dinamika kehidupannya, manusia berupaya terus menyesuaikan dengan kondisi lingkungannya. Bagaimana sikap dan perilaku suatu masyarakat terhadap lingkungannya dapat terungkap pula melalui berbagai tradisi dan ketentuan yang dipatuhi bersama. Salah satu tradisi yang merepresentasikan pandangan-pandangan terhadap lingkungan itu adalah bahasa. Berbagai ekspresi, misalnya kekaguman, keindahan, dan bahkan kedasyatan alam, terekam melalui bahasa. Oleh karena itu, pengkajian terhadap bentuk pengetahuan masyarakat lokal (bahasa) tentang lingkungannya menjadi penting dan strategis.

Masyarakat Sunda merupakan salah satu masyarakat yang memiliki perhatian terhadap lingkungan. Di beberapa tempat, masyakarat Sunda mengelola lingkungan dengan baik dengan tunduk pada kapamalian (pertabuan) sehingga kualitas lingkungan hidup masyarakat setempat pun terjaga. Banyak ekspresi kebahasaan yang memiliki nilai filosofi tinggi berkaitan dengan lingkungan. Misalnya, dalam masyarakat Sunda dikenal peribahasa herang caina, beunang laukna (jernih airnya, ikannya dapat). Peribahasa tersebut memperlihatkan masyarakat yang dalam kesehariannya berorientasi dan dekat dengan lingkungan alam yang menyangkut air dan ikan. Air dalam pemahaman di sini tidak hanya kolam, tetapi juga sungai dan lainnya. Bagaimana mungkin akan terdapat ikan di sungai jika habitat tempat ikan itu hidup 
(sungai), sudah tercemar limbah industri. Penggalian cara pandang masyarakat terhadap alam melalui nilai budaya tentu menjadi penting. Pemahaman konservasi tanpa dilandasi pemahaman budaya lokal tidak akan berhasil. Oleh karena itu, penggalian nilai-nilai budaya seperti ini perlu dilakukan agar masyarakat tidak hanya menjadi objek pembangunan (konservasi), tetapi menjadi subjek pemeliharaan lingkungan alam (baca pula Sobarna dkk., 2015).

Masyarakat yang masih jauh dari peradaban kota sebagian masih memegang kepercayaan yang kuat dalam kehidupan sehari-harinya. Dalam masyarakat Baduy, misalnya, konsep tentang hutan titipan dapat dipandang sebagai upaya pelestarian alam yang melibatkan pemahaman masyarakat setempat akan pentingnya arti lingkungan. Masyarakat Baduy tidak berani mengganggu hutan itu, dan andaikata tidak memeliharanya, mereka merasa dosa. Hal itu terjadi karena Orang Baduy merasa bahwa hutan merupakan titipan dari para leluhurnya harus dipusti-pusti demi kelangsungan generasi selanjutnya. Dengan demikian, konsep keselarasan alam tetap terjaga. Di hutan Baduy diduga masih banyak tumbuhan yang terkonservasi dengan baik. Hal inilah tentu yang seyogianya menjadi fokus perhatian semua pihak, terlebih lagi masyarakat daerah yang memiliki kekaayaan hayati di wilayahnya. Oleh karena itu, pengkajian dan penanggulangan yang berkaitan dengannya mendesak dilakukan. Seakan berpacu dengan waktu, pengaruh globalisasi yang sudah merasuk ke bebagai sendi kehidupan di mana pun tidak boleh dianggap sepele karena lambat laun akan mengubah tatanan hidup masyarakat, termasuk kearifan berpikir dan bertindak terhadap lingkungan alamnya. Bahkan, Hamzah (2013: 6) lebih tajam menyebut bahwa kita tengah bunuh diri pelan-pelan secara ekologis.

\section{METODE}

Metode merupakan cara kerja yang teratur, terpikir baik, dan bersistem untuk memudahkan pelaksanaan suatu kegiatan guna mencapai tujuan yang telah ditentukan (Djajasudarma, 2010: 1). Oleh karena itu, pemilihan metode yang tepat dalam suatu kegiatan dapat memaksimalkan pencapaian tujuan. Metode deskriptif-sinkronis dipilih dengan pertimbangan ciri-ciri dan sifat-sifat data sebagaimana adanya.

Penelitian ini menggunakan metode lapangan karena peneliti terjun langsung ke masyarakat dengan teknik pengumpulan data utama dengan perekaman. Perekaman dilakukan untuk memperoleh data bahasa ragam lisan. Untuk mendapat data yang sahih digunakan teknik simak libat cakap mengingat peneliti langsung berpartisipasi dalam pembicaraan dan menyimak informan. Di samping itu, peneliti ini menggunakan teknik pancing dengan cakap semuka (lihat Sudaryanto, 1993: 137). Pelaksanaan teknik ini dilakukan melalui percakapan langsung antara peneliti dan informan. Peneliti mengarahkan percakapan sesuai dengan kepentingan untuk memperoleh data yang selengkap-lengkapnya sesuai dengan jenis data yang diinginkan.

Metode kajian yang digunakan untuk menganalisis data mengacu pada teori dialektologi. Data dikaji berdasarkan jenis variasi, yakni fonologis dan leksikal. Variasi fonologis didasarkan pada asumsi adanya pengaruh dari lingkungan, dalam hal ini bahasa Jawa. Sebagaimana disebutkan oleh Soemaryatmi (2012: 27) bahwa perubahan suatu masyarakat pasti terjadi sebagai sebuah konsekuensi logis dari perkembangan sosio kultural. Dengan demikian, terkait dengan berkontaknya dua kebudayaan, termasuk di dalamnya bahasa, Pedersen (2017: 24-26) menegaskan bahwa keadaan tersebut dapat berpengaruh terhadap nama tempat, baik secara struktur fonologis maupun secara semantis. Di samping itu, data 
penelitian dikaji berdasarkan struktur morfologis dan frase. Unsur bahasa yang terekam diklasifikasi berdasarkan bentuk: dasar dan turunan.

Data yang dikaji dalam penelitian adalah "artefak" budaya Sunda yang masih ada di wilayah Jawa Tengah, khususnya di Kabupaten Banyumas. Penelusuran dilakukan pada nama-nama tempat yang berbahasa Sunda. Di kabupaten ini tidak banyak yang dijadikan informan mengingat penduduk asli yang berbahasa Sunda tinggal beberapa orang saja. Oleh karena itu, pengumpulan data difokuskan pada berbagai aktivitas informan yang memenuhi kriteria keaslian tersebut.

Sebagai data pendukung, penelitian ini juga memanfaatkan informan lain yang dapat menggunakan bahasa Sunda. Di Desa Dermaji tinggal beberapa orang yang bisa berbahasa Sunda meskipun bukan asli bahasa Sunda Dermaji. Hal ini tampak dari kata-kata yang digunakan melalui pengamatan sekilas, yakni dikenalnya kata-kata halus, seperti muhun. Padahal, diduga bahasa Sunda yang tersebar di wilayah bagian barat Jawa Tengah tidak mengenal undakusuk seperti bahasa Sunda yang digunakan di wilayah Priangan.

\section{HASIL DAN PEMBAHASAN}

\section{Toponimi Berbahasa Sunda di Kabupaten Banyumas}

Toponimi di wilayah Kabupaten Banyumas sebagai salah satu tinggalan budaya Sunda masa silam yang ada di Jawa Tengah masih dapat dilacak, baik pada individu masyarakat maupun pada penamaan daerah. Sekalipun dua provinsi ini dipisahkan oleh kabupaten masing-masing, tetapi kenyataannya, baik nama tempat maupun budayanya, tidak ketat memisahkan antara budaya (bahasa) Sunda dan Jawa. Hal ini terjadi mengingat di wilayah Jawa Tengah banyak ditemukan nama tempat yang berasal dari bahasa Sunda.
Di Kabupaten Banyumas, terdapat beberapa nama tempat berbahasa Sunda yang menarik untuk dikaji keterkaitannya dengan budaya Sunda di Jawa Tengah. Nama-nama itu telah menjadi pembuka jendela awal akan pemahaman sejarah budaya Sunda, khususnya di wilayah Jawa Tengah pada masa silam.

\section{Nama-nama Kampung Randegan}

Desa Randegan berada di Kecamatan Wangon, Banyumas. Secara kebahasaan, Randegan berasal dari kata randeg 'berhenti sebentar' ditambah sufiks -an. Jadi, Randegan berarti tempat yang dijadikan untuk tempat berhenti sebentar atau beristirahat ketika dalam suatu perjalanan. Menurut cerita rakyat setempat, dulunya tempat ini merupakan tempat beristirahatnya Raden Kamandaka. Beberapa tempat di Kabupaten Banyumas memang selalu berkaitan dengan legenda Raden Kamandaka atau yang dikenal juga si Lutung kasarung. Masyarakat sekitar percaya bahwa dulu di sana Raden Kamandaka pernah ngarandeg (berhenti sebentar untuk beristirahat) dari kejaran prajurit-prajurit Adipati Kandha Daha yang berniat untuk menangkap dan membunuhnya. Tempat perhentian itu kemudian dinamai Kampung Randegan.

\section{Pangadegan}

Desa Pangadegan lokasinya tidak jauh dari Desa Randegan. Pangadegan berasal dari kata ngadeg 'berdiri' yang dibubuhi oleh prefiks $p a$ - dan sufiks -an, yang berarti tempat berdiri. Sasakala Pangadegan merupakan rangkaian dari cerita Kamandaka. Menurut informasi, Kamandaka dalam pengejarannya, Raden Kamandaka ketika sedang berdiri (bahasa Sunda: ngadeg) sempat terkejar oleh prajurit-prajurit Adipati Kandha Daha. Sejak saat itulah tempat tersebut dikenal dengan sebutan Pangadegan. Versi lain menyebutkan Pangadegan ber- 
asal dari kata pangudagan dari kata bahasa Sunda udag 'kejar', yang berarti tempat untuk mengejar.

\section{Cingebul}

Nama tempat, sebagaimana telah disebutkan, merupakan suatu bentuk cerita dan sejarah yang secara tradisi diturunkan di antaranya melalui folklor (Danandjaja, 2004) yang menelusuri proses penamaan (naming) berbagai hal. Dalam hal penamaan tempat misalnya sejarah penamaan Cingebul (Bahasa Sunda: Ci 'air', ngebul 'berasap') di wilayah Kecamatan Lumbir, Banyumas. Menurut keterangan dari informan, pada masa perang Diponegoro kurang lebih tahun 1929, saat pasukan Diponegoro mulai terpukul mundur oleh pasukan Belanda, ada dua prajurit Pangeran Diponegoro bernama Wirantaka dan Naya Pati yang terpisah dari pasukannya, mereka berjalan tanpa arah karena tidak tahu wilayah Banyumas. Dalam pelariannya, sampailah pada suatu tempat di antara dua bukit di selatan Karangpucung (Kecamatan di Kabupaten Cilacap) untuk dijadikan tempat persembunyian mereka. Karena dirasa aman mereka menetap di sana, lalu bersama Suradiporata (keluarga prajurit Pajajaran) mendirikan sebuah padepokan untuk menyebarkan agama Islam. Satu waktu sebelum matahari terbit, para santri setelah melaksanakan salat subuh dan pengajian bersama, mereka bercengkrama sambil membakar singkong di pinggir sungai, tiba-tiba Suradipota melihat ada asap keluar dari atas air di hulu sungai. Dalam keheranannya Suradipota berteriak sambil menunjuk ke arah hulu sungai 'oe..cai ngebul..., cai ngebul..', seorang santri yang mendengarnya berlari ke padepokan untuk melaporkan pada Wirantaka supaya melihat kejadian tersebut. Kepada Wirantaka santri itu berkata, 'aya cai ngebul... cai ngebul... ." Setelah melihat langsung, Wirantaka menyatakan bahwa daerah tersebut adalah daerah Cingebul. Sampai sekarang pun, menurut informan, beberapa warga masih ada yang beberapa kali melihat air di sana mengeluarkan asap.

\section{Gumelar}

Gumelar adalah salah satu kecamatan di Kabupaten Banyumas. Kata gumelar sendiri berasal dari bahasa Sunda gelar 'terlihat dan bukti ada di dunia, lahir, ngampar' yang dibubuhi sisipan -um- sebagai pemarkah progresif. Menurut cerita rakyat yang berkembang di sana, dulunya daerah Gumelar ini sering dijadikan tempat berkumpulnya banyak orang untuk mengungsi atau bersembunyi. Banyaknya orang yang berkumpul di sana terlihat seperti nu gumelar atau ngampar 'terhampar'. Oleh karena itulah daerah tersebut diberi nama Gumelar yang sekarang menjadi nama desa dan juga kecamatan.

Konon di wilayah Gumelar ini dulunya banyak hidup binatang buas yang memangsa manusia. Di sana, di satu tempat, sering ditemukan penduduk yang babak 'terluka' karena serangan binatang buas. Sekarang kampung ini disebut kampung Babakan. Penduduk yang menemukan orang-orang yang terluka di sana selalu menolongnya dengan cara membawanya dengan cepat ke suatu kampung yang sekarang diberi nama Ciwaras. Waras dalam bahasa Sunda berarti sehat/sembuh. Di Ciwaras ini ada orang pintar yang bisa menyembuhkan mereka yang terluka oleh serangan binatang buas. Jalur antara Babakan dan Ciwaras sekarang disebut dengan nama kampung Gancang. Gancang dalam bahasa Sunda ber-arti cepat, buru-buru. Namun, bagi penduduk yang tidak tertolong atau meninggal karena serangan binatang buas itu oleh penduduk lainnya dikumpulkan di suatu tempat untuk memudahkan keluarga atau kerabat mencari anggota keluarganya yang hilang. Menurut cerita, biasanya mayat-mayat tersebut hanya ditutupi oleh 
daun pisang atau daun jati. Setiap orang yang melewati tempat tersebut selalu $n y$ ingkabkeun (membuka) daun pisang atau daun jati yang menutupi karena ingin tahu siapa yang meninggal. Oleh karena itulah, tempat tersebut diberi nama Paningkaban (tempat membuka).

Di Gumelar ada desa yang bernama Cionje. Cionje ini berasal dari kata $c i+$ honje 'nama tumbuhan yang buahnya suka dijadikan bumbu masak'. Tempat tersebut diberi nama Cionje karena sampai sekarang pun di daerah tersebut banyak tumbuh honje. Perubahan kata honje menjadi onje disebabkan faktor lingkungan fonologis bahasa Jawa. Di Desa Cionje ini ada satu daerah yang bernama Ciuyah. Wilayah Ciuyah berada di pinggiran bukit hutan pinus milik Perhutani. Tempat tersebut disebut Ciuyah karena di wilayah itu ada sumber air yang mengeluarkan air yang rasanya asin seperti uyah 'garam'. Air itu keluar dari kubangan dari bawah batu dengan diameter sekitar tiga puluh sentimeter. Dari celahcelah batu tampak gelembung-gelembung air yang menandakan keluarnya sumber air. Hingga saat ini masyarakat sekitar masih memanfaatkan sumber air asin Ciuyah untuk ngasini yaitu tradisi memberikan air garam pada hewan ternak. Dahulu tradisi ini dilakukan dengan cara membawa ternak peliharaannya ke sumber mata air asin tersebut. Namun, sekarang warga hanya mengambil airnya lalu memberikannya pada ternak peliharaan di kandang. Menurut informan, selain untuk tradisi ngasini, air asin yang keluar dari sumber mata air Ciuyah dulunya juga pernah dimanfaatkan oleh warga sekitar untuk membuat garam. Dari penuturan warga, sumber mata air tersebut tidak pernah kering meskipun sedang kemarau panjang. Bagi masyarakat Ciuyah yang mayoritas bermata pencaharian sebagai buruh tani, keberadaan sumber mata air asin sangat bermanfaat terutama untuk hewan ternaknya.

\section{Dermaji}

Selain banyaknya nama tempat berbahasa Sunda di Kabupaten Banyumas, beberapa warga di Desa Dermaji Kecamatan Lumbir masih ada yang menggunakan bahasa Sunda. Dari cerita-cerita lisan warga setempat diyakini bahwa Desa Dermaji termasuk salah satu desa yang keberadaanya sudah cukup tua. Desa Dermaji diperkirakan sudah ada pada masa-masa berdirinya Kerajaan Galuh, Jawa Barat pada abad ke-6. Desa Dermaji masuk wilayah Kerajaan Galuh. Oleh karena masuk dalam wilayah Kerajaan Galuh yang berbudaya Sunda, kehidupan masyarakat Desa Dermaji pun juga tidak lepas dari pengaruh budaya Sunda. Pengaruh paling besar bisa dilihat dari bahasa yang dipakai warga Desa Dermaji. Bahasa Sunda pernah menjadi bahasa tutur masyarakat Dermaji. Nama-nama tempat dan sungai, seperti, Cireang, Cukangawi, Cipancur, Citunggul, Cipeundeuy, Ciberewek, dan Cijurig menunjukkan adanya pengaruh kuat bahasa Sunda di Desa Dermaji. Beberapa kosa kata bahasa Sunda di Desa Dermaji tidak lagi ditemukan pada pengguna bahasa Sunda yang berada di wilayah Bandung dan sekitarnya (wilayah Priangan), tetapi memiliki banyak kesamaan dengan bahasa Sunda di wilayah Banten.

Cerita lain menyebutkan, sebelum dihuni oleh manusia, Desa Dermaji berwujud hutan belantara yang di dalamnya hidup binatang buas, jin, dan siluman. Mbah Damarwulan, Mbah Panusupan, dan Mbah Jayasengara dianggap sebagai para leluhur yang berjasa besar dalam mendirikan Desa Dermaji. Merekalah yang mengusir jin dan siluman jahat sehingga Desa Dermaji dapat dihuni oleh manusia hingga sekarang. Warga Desa Dermaji juga memiliki leluhur yang dikenal dengan nama Mbah Darmokusumo. Mbah Darmokusumo ini seringkali digambarkan sebagai sosok yang memiliki tingkat kejujuran yang tinggi dan totalitas kepasrahan kepada sang Ilahi. Bagi 
warga Dermaji, sosok Darmokusumo menjadi sosok yang dibanggakan karena memiliki banyak keutamaan dalam perilaku. Oleh karena keutamaan-keutamaan perilakunya tersebut, sosok Darmokusumo seringkali dikait-kaitkan dengan asal-usul nama Dermaji. Derma berarti memberi, aji berarti sesuatu yang berharga. Nama Dermaji mengandung makna dan semangat untuk selalu memberikan kebaikan terusmenerus kepada sesama.

\section{Nama Sungai}

Sungai Cikalong adalah salah satu sungai yang mengalir melintasi Desa Cikakak. Menurut keterangan dari informan, karena dulunya di sungai tersebut banyak kalong 'kelelawar', masyarakat menyebut sungai itu Cikalong. Selain Cikalong, ada lagi sungai yang penamaannya mengacu pada nama hewan, yaitu Sungai Ciaur. Sungai Ciaur mengalir melintasi Desa Cingebul dan beberapa desa lainnya di Kecamatan Lumbir. Menurut informan kata ciaur berasal dari kata ci atau cai yang berarti air, dan aur atau haur yang merupakan nama jenis burung. Menurut warga setempat, di sepanjang sungai Ciaur banyak ditemukan sarang burung haur, karena itulah sungai ini disebut Ciaur. Versi lain menyebutkan, dikatakan Sungai Ciaur karena sepanjang aliran Sungai Ciaur banyak tumbuh haur atau 'bambu'.

Selanjutnya ada Sungai Cikadu dan Cipakis yang melintasi Desa Cikakak. Namanama sungai ini diambil dari nama-nama tumbuhan yang tumbuh di sekitar sungai tersebut. Di sekitar aliran Sungai Cikadu dulunya banyak pohon kadu 'durian', dan di sekitar Sungai Cipakis banyak ditemukan tumbuhan pakis. Selain kedua sungai itu, ada juga sungai lain yang penamaannya berdasarkan tumbuhan yang ada di sekitar aliran sungainya, yaitu Sungai Ciwitali di Gumelar dan Sungai Cipandan di Lumbir. Ciwitali berasal dari kata ci dan awi tali 'je- nis bambu'. Kemudian kata cipandan berasal dari ci dan pandan 'tumbuhan yang daunnya seperti daun kelapa, tetapi tidak berlidi dan biasa dijadikan pewangi alami makanan'.

Salah satu sungai di Kabupaten Banyumas tepatnya di Kecamatan Lumbir yang penamaannya gabungan dari bahasa Sansekerta dengan bahasa Sunda, yaitu Sungai Lopasir. Lo atau dikenal juga dengan kata loh berasal dari bahasa Sansekerta yang berarti bengawan/sungai, sedangkan pasir merupakan kata bahasa Sunda yang berarti 'bukit'. Tempat itu disebut Lopasir karena menurut informasi hulu sungai itu berada di pasir 'bukit' yang ada di Kecamatan Lumbir.

\section{Nama Gunung}

Gunung Batur berada di Cirahab Kecamatan Lumbir. Dalam bahasa Sunda, batur berarti 'teman, orang lain'. Gunung Batur dalam legenda Kamandaka merupakan tempat bertapa Raden Kamandaka untuk meminta petunjuk bagaimana caranya bisa mendapatkan wanita pujaannya, Ciptarasa. Menurut cerita, di gunung ini Raden Kamandaka bertemu dengan seorang kyai yang menemani (bahasa Sunda, ngabaturan) dia bertapa lalu menghilang setelah memberikan sebuah pakaian yang bisa mengubah Kamandaka menjadi Lutung apabila memakainya. Dari sinilah cerita Lutung kasarung yang melegenda di Banyumas dimulai.

\section{Nama Air Terjun/Curug Curug Cipendok}

Curug Cipendok bermula dari legenda yang juga masih berkaitan dengan sejarah Perang Diponegoro. Salah satu wilayah Banyumas, yaitu Ajibarang, saat itu dipimpin oleh seorang Wedana Priangan Timur bernama Raden Ranusentika. Pada saat itu dia diberi tugas untuk melakukan kerja paksa, berupa pembukaan hutan belantara 
di sekitar lereng Gunung Slamet untuk dijadikan area perkebunan. Sudah delapan bulan lamanya dia memimpin pembukaan hutan di lereng Gunung Slamet, tetapi belum juga mendapatkan hasil. Terjadi keanehan, pada saat pohon-pohon selesai ditebang, esoknya tumbuh lagi seperti semula. Seolah-olah seperti belum pernah ditebang sama sekali. Kejadian ini terjadi berulangulang sehingga membuat bingung dan geram Raden Ranusentika. Oleh karena itu, Raden Ranusentika berdoa dan bermohon kepada Tuhan dengan cara bertapa di sebuah air terjun. Karena merasa belum mendapat petunjuk juga, dia kemudian menyudahi tapanya. Sembari mengusir kegundahan dan mencari jalan keluar, Raden Ranusentika pergi memancing ikan di dekat air terjun. Pada saat memancing, tiba-tiba dia merasa kailnya seperti ditarik-tarik oleh ikan yang besar, sampai gagang pancingnya melengkung. Namun, alangkah terkejutnya saat pancingnya ditarik, bukannya ikan yang didapat, melainkan sebuah barang mirip cincin yang merupakan pendok atau cincin warangka keris yang bersinar kuning keemasan. Ketika didekatkan, tiba-tiba Raden Ranusentika bisa melihat banyak sekali makhluk halus yang berada di hutan. Mereka semua yang selama ini menggagalkan pekerjaan Raden Ranusentika. Selain menemukan pendok, Raden Ranusentika juga ditemui seorang makhluk halus berujud peri, bernama Dewi Masinten Putri Sudhem yang bersedia membantu menyelesaikan pekerjaan pembukaan hutan tersebut. Akhirnya, pekerjaan pembukaan hutan berhasil diselesaikan dengan baik. Dewi Masinten Putri Sudhem kemudian diboyong ke Kadipaten Ajibarang, menjadi garwa padmi (selir) dari Raden Ranusentika. Atas usulan Breden Santa, seorang kepala pekerja, air terjun tempat Raden Ranusentika menemukan pendok keris, dinamakan Curug Cipendok.

\section{Curug Gumawang}

Selain Curug Cipendok, air terjun di Kabupaten Banyumas yang namanya berbahasa Sunda, yaitu Curug Gumawang. Gumawang berasal dari bahasa Sunda yang berarti seperti gawang 'guratan tanah' yang berasal dari awang-awang 'angkasa' dan bercahaya. Curug Gumawang berada di Desa Kemawi, Kecamatan Somagede, Kabupaten Banyumas, sekitar $15 \mathrm{~km}$ ke arah tenggara Kota Banyumas. Nama Gumawang menurut warga setempat diberikan mengingat curug tersebut tinggi, sekitar 60 meter, diibaratkan turun dari angkasa. Curug Gumawang mempunyai tujuh tingkatan genangan air yang disebut dengan kedung 'leuwi', bagian sungai yang dangkal biasanya ada di antara dua leuwi'. Apabila dilihat dari bawah, hanya akan terlihat tiga tingkatan, tingkatan paling besar yang nomor dua dari bawah. Tingkatan atas juga terlihat bertingkat, tetapi tidak terlalu tinggi dan hanya bisa dilihat dari jalan menuju Curug Gumawang. Tujuh tingkatan kedung yang terdapat di Curug Gumawang adalah Kedung Pundak, Kedung Tumbu, Kedung Dhandhang, Kedung Wuluh, Kedung Wungu, Kedung Nyai Gendur, dan Kedung Jojogan. Hingga saat ini, kedung yang dikeramatkan oleh warga adalah Kedung Pundak. Menurut kuncen Curug Gumawang, di kedung ini terdapat sepasang suami istri, yaitu Mbah Weno Werso dan Nyai Dewi Welasari sebagai penunggu kedung. Dikatakan juga ada Mbah Bondowoso yang berada di bawah pohon bambu Ampel Kuning. Dalam versi lain, curug ini berasal dari kata gemawang, menurut cerita warga setempat, nama $\mathrm{Cu}$ rug Gemawang berasal dari kata gema yang berarti bergema dan awang yang memiliki arti angkasa. Jadi, nama Curug Gumawang berarti air terjun yang yang jatuh dari ketinggian, dengan suara yang menggema sampai terdengar jauh ke angkasa. Bahkan, suara yang menggema itu dapat didengar oleh masyarakat di desa lain. Masyarakat 
setempat meyakini jika pengunjung berkendara melewati sebuah kuburan di kanan jalan saat menuju lokasi curug harus membunyikan klakson sebagai tanda untuk meminta izin lewat. Masyarakat setempat percaya khasiat air di kedung paling tinggi di Curug Gumawang. Apabila digunakan untuk mandi atau mencuci muka, dipercaya dapat membuat awet muda dan diberikan kemudahan rejeki. Akses jalan yang dilalui untuk menuju ke Air Terjun Gemawang bisa dikatakan buruk. Hal ini disebabkan oleh sebagian besar aspal dalam kondisi terkelupas dan bergelombang. Sekarang akses jalan ke Curug Gumawang sudah dibangun. Pelebaran jalan dilakukan dari Beji atau Tapak Bima (sebuah area yang berbentuk seperti telapak kaki yang sangat besar) sampai ke tempat wisata Curug Gumawang. Nama yang hampir sama dengan Curug Gumawang juga ditemukan jauh dari Kabupaten Banyumas, yaitu Curug Cigumawang di Kabupaten Banten Jawa Barat.

\section{Toponimi sebagai Representasi Kesadaran Ekologis}

Kajian toponimi terkait pula pandangan dan pemahaman terhadap lingkungannya, terutama men-cerminkan identitas masyarakatnya, atau sebagai bentuk branding dari tempat tersebut, bahkan branding suatu negara (Anholt, 2010; Kostanski, 2011). Akan tetapi, Hall $(1998,1997)$ dan Woodward (2004) berpendapat bahwa identitas tidaklah ajek. Identitas akan terus-menerus berubah. Begitu juga dengan nama tempat walaupun nama tempat cenderung melekat, identitas yang menyertainya dapat saja berubah. Dengan demikian, toponimi juga dapat memberi gambaran budaya masa silam dan bagaimana pergerakan manusia terjadi di sebuah daerah atau wilayah. Anholt (2010) menyebutkan bahwa toponimi juga berfungsi sebagai bentuk identitas nasional yang dalam hal ini berkontribusi

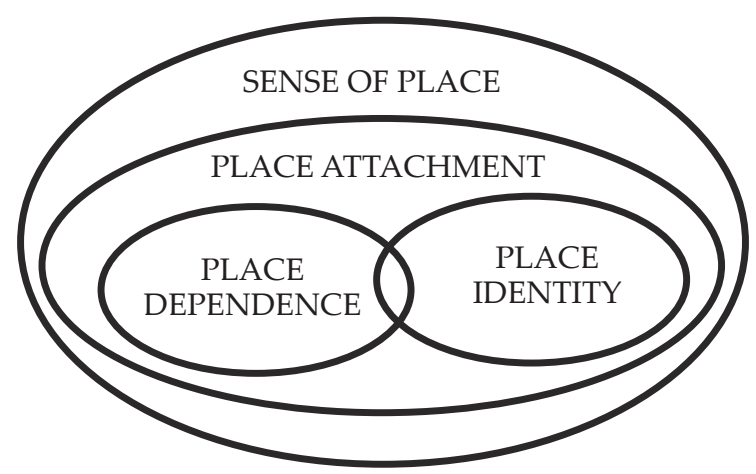

Gambar 1: Kedudukan toponimi dalam pembentukan "sense of place"

(Kostanski, 2011: 14; lihat pula Sobarna dkk., 2015, 2016).

terhadap kedaulatan sebuah negara. Kondisi ini dapat dipahami mengingat pemberian nama tempat tentu dengan berbagai pertimbangan, terutama yang menyangkut kesejarahan, sekaligus juga sebagai upaya pelestarian budaya (bahasa). Hal senada ditegaskan pula oleh Rais dkk. (2008: xi) bahwa banyak nama tempat berakar dari sejarah dan kebudayaan bangsa (masyarakat) itu sendiri.

Sebagaimana telah diuraikan pada bagian terdahulu, toponimi secara literal berarti nama tempat (baca pula Rais dkk., 2008:5-6). Berbagai penelitian menyebutkan bahwa nama tempat mengisyaratkan juga keterikatan dengan tempat tersebut. Menurut Jorgensen dan Stedman, sebagaimana dibahas oleh Kostanski (2011), keterikatan dengan suatu tempat merupakan konsep yang dapat dikategorikan ke dalam istilah sense of place sejalan dengan konstruk atas identitas tempat dan kebergantungan terhadap tempat. Kostanski menguraikan keterkaitan tersebut, lihat pada gambar 1.

Dalam kaitannya dengan penelitian ini, toponimi berhubungan dengan kearifan lokal sebagai bagian penting dalam menjaga kelestarian lingkungan melalui sense of place yang hanya bisa dibangun melalui rasa keterikatan dengan tempat tersebut. William dan Vaske, sebagaimana didiskusikan Kostanski (2011: 14), menyebutkan adanya dua keterikatan. Yang pertama, ke- 
bergantungan terhadap suatu tempat (place dependence) yang merupakan keterikatan fungsional terhadap suatu tempat dan yang kedua adalah "identitas tempat" yang merupakan keterikatan emosional terhadap tempat tersebut. Dengan demikian, toponimi merupakan penanda signifikansi tempat dalam konteks fungsional sebagai sumber bagi pemenuhan berbagai kebutuhan dan juga sebagai investasi psikologis terhadap tempat tersebut.

Toponimi bagaimanapun adalah ungkapan yang dalam teori linguistik dapat dilihat sebagai 'tanda', yang dalam hal ini tidak dapat dengan sederhana dianggap terjadi secara arbitrer. Seperti diargumentasikan Radding \& Western (2010: 399), konteks di antara kata-kata yang arbitrer di dalam suatu bahasa tertentu dan dalam situasi tertentu di dalam bahasa tertentu tidaklah artbitrer. Kita mencintai dan memedulikan nama tertentu karena nama tersebut mengandung lapisan makna yang berasal dari budaya tempatnya berada yang melampaui kata-kata sehari-hari atau biasa. Dengan demikian, toponimi harus dapat dipahami sebagai sebentuk 'tanda'.

Dalam hal ini, suatu nama tempat merupakan suatu tanda yang mengacu kepada suatu cerita (story) dan juga sejarah (history) yang berakar dalam budaya lokal. Perubahan dalam suatu budaya akan mengakibatkan perubahan pemaknaan terhadap nama tempat itu sebagai tanda (Radding \& Western, 2010). Misalnya, di Kecamatan Lumbir Kabupaten Banyumas, beberapa nama tempat di sana diubah oleh tokoh-tokoh masyarakat setempat karena dianggap memiliki makna negatif dan dipercaya sebagai penyebab buruknya perilaku warga di sana. Nama-nama tersebut adalah Ciwikwik berubah menjadi Karangreja, Cilutung menjadi Bojanegara, dan Cingepret berubah namanya menjadi Rejasari. Berdasarkan penelusuran dan informasi dari informan, Ciwikwik, berasal dari kata wikwik yang berarti 'cerewet, suka membicarakan orang lain, suka adu omong,' yang dipercaya sebagai penyebab kurang harmonisnya kehidupan warga dengan seringnya terjadi pertengkaran antarwarga. Kemudian Cilutung, yang berasal dari kata ci + lutung 'lutung, sebangsa kera'. Menurut informan, di daerah tersebut dulunya memang banyak lutung sehingga daerah tersebut diberi nama Cilutung. Namun, nama Cilutung juga diduga sebagai penyebab seringnya terjadi perkelahian, saling cakar seperti lutung, antarwarga di daerah tersebut. Dengan demikian, salah seorang kepala desa dulu mengubah nama daerah tersebut menjadi Bojanegara yang memiliki makna baik dengan harapan tingkah laku warganya juga berubah menjadi baik. Begitu pula dengan Cingepret, namanya diubah karena memiliki makna negatif. Cingepret menurut informan berasal dari kata ngéprét 'menampar'. Berdasarkan data tersebut, ketiga nama daerah tersebut diubah karena memiliki makna yang kurang baik dan dianggap sebagai penyebab sering terjadinya perselisihan antarwarga di sana.

Selain itu, pemaknaan suatu nama juga dapat ditelusuri melalui cerita (sastra) atau sejarah yang menyertainya, terutama melalui cerita atau tradisi lisan yang menurunkan cerita/sejarah nama tempat tersebut, sekalipun disadari bahwa sastra dan sejarah memiliki sifat yang berbeda (Muhsin, 2012: 139). Tradisi ini berkontribusi besar bukan saja untuk melanggengkan nama, tetapi yang lebih dalam lagi, melanggengkan narasi yang menyertainya serta nilai-nilai yang tertanam di dalamnya, terutama yang menyangkut kehidupan sosial-budaya.

Sebagaimana sudah dijelaskan di muka, penamaan bersifat konvensional dan arbitrer. Hal ini dikatakan konvensional karena disusun berdasarkan kebiasaan masyarakat pemakainya, sedangkan dikatakan arbitrer karena tercipta berdasarkan kemauan masyarakatnya. Nama sungai 
Cibrewek, misalnya, masyarakat Desa Dermaji Kabupaten Banyumas menyebut sungai tersebut Cibrewek karena dulunya banyak bebek di sungai tersebut. Oleh karena seringnya mendengar suara bebek di sana, masyarakat sepakat memberi nama sungai tersebut Cibrewek. Sampai sekarang walaupun sudah tidak ada lagi bebek, tetapi menurut informan beberapa warga masih suka ada yang mendengar suara-suara bebek mistis di sekitar sungai tersebut.

Masyarakat Sunda di Banyumas juga mempertimbangkan penamaan tempat tersebut dengan lingkungan alam tempat mereka hidup, sebagai bentuk kesadaran ekologis. Hal tersebut dapat dilihat dari penamaan tempat yang cenderung berkaitan erat dengan latar lingkungan alamnya. Penamaan tempat di wilayah tersebut pada umumnya sebagian besar dihubungkan dengan tumbuhan (flora) dan binatang (fauna). Beberapa nama tempat yang terkait dengan tumbuhan (flora) yang terjaring dalam penelitian kemungkinan besar tumbuhan yang menjadi unsur nama tempat itu dapat ditelusuri dan pernah tumbuh di daerah tersebut, sebagaimana dapat diamati nama tempat di wilayah Kabupaten Banyumas. Unsur nama tempat tersebut merupakan perpaduan leksem antara nama/jenis tumbuhan dan tempat/ habitat tempat tumbuhan itu hidup, di antaranya $c i$ 'air, sungai, kolam' dan karang 'karang'. Nama tumbuhan tersebut di antaranya adalah kadu, pakis, dadap, waru, honje, kawung, langkap, pandan, dan awi tali, sebagaimana pada nama kampung Cikadu, Cipakis, Karangdadap, Ciwaru, Cihonje, Cikawung, Cilangkap, Cipandan, dan Ciwitali. Adapun nama tempat yang berkaitan de-ngan binatang (fauna), di Banyumas terdapat nama tempat yang unsurnya adalah binatang, sebagaimana terkandung pada nama desa/kampung Cibangkong, Cihaur, Cilutung, Cikalong, dan Cikidang. Bangkong (katak) banyak ditemukan di sawah, haur merupakan salah satu jenis burung, kalong merupakan sejenis kelelawar, lutung 'sejenis kera', dan kidang adalah hewan berkaki empat sejenis seperti kijang.

\section{SIMPULAN}

Berdasarkan uraian sebelumnya, dapat dilihat bahwa nama-nama tempat berbahasa Sunda di Kabupaten Banyumas memiliki aturan, kaidah, atau sistem tertentu, dan tidak dibuat sembarangan. Setiap nama tempat memiliki latar belakang sasakala (kesejarahan atau historis) tertentu. Latar sasakala ini berkaitan dengan aspek geografis, sosial, dan aspek kebudayaan (kultural). Aspek geografis mencakup latar perairan, rupa bumi, dan latar lingkungan alam seperti tumbuhan (flora) dan binatang (fauna). Pemberian nama tempat tidak hanya melihat aspek geografisnya, tetapi lebih luas lagi yakni aspek budaya masyarakat serta nilai-nilai sejarahnya.

Penamaan tempat suatu daerah dapat dilihat dari berbagai segi, antara lain dari cerita rakyat (legenda) dari segi sejarah atau historis. Legenda merupakan cerita rakyat yang menceritakan tokoh terkenal pada masanya, seperti cerita Kamandaka misalnya, banyak ditemukan di Banyumas nama-nama tempat yang dilatarbelakangi oleh cerita tersebut. Selain menceritakan tokoh terkenal, legenda juga biasanya menceritakan tentang terjadinya peristiwa alam, manusia, flora, dan fauna. Hal ini dapat dilihat dari penamaan tempat yang cenderung berkaitan erat dengan latar lingkungan alamnya. Penamaan tempat di Banyumas yang berbahasa Sunda, pada umumnya sebagian besar dihubungkan dengan tumbuhan (flora) dan binatang (fauna). Beberapa nama tempat yang terkait dengan tumbuhan (flora) yang terjaring dalam penelitian kemungkinan besar tumbuhan yang menjadi unsur nama tempat itu dapat ditelusuri dan pernah tumbuh di daerah tersebut. 
Di samping dilihat dari segi legenda, toponimi bahasa Sunda di Banyumas dapat pula dilihat dari berbagai versi dan cara, yaitu dari segi sejarah atau historis. Ada beberapa nama tempat di Banyumas yang dilatarbelakangi oleh historis, khususnya oleh sejarah perjuangan Pangeran Diponegoro. Kabupaten Banyumas merupakan salah satu tempat Pangeran Diponegoro bergerilya melawan penjajah Belanda. Daerah-daerah yang disinggahi oleh Diponegoro misalnya di Cikakak, Cilongok, dan Randegan di Kecamatan Wangon. Selain itu, Desa Cingebul Lumbir, sebagaimana telah dijelaskan sebelumnya, penamaan daerah tersebut juga berkaitan erat dengan Diponegoro.

\section{Daftar Pustaka}

Anholt, S. (2010). Places: Identity, Image and Reputation. Palgrave: Macmillan.

Bachtiar, T. dkk. (2008). Toponimi Kota Bandung. Bandung: Bandung Art and Culture Council.

Halim, A. (Ed.). (1976). Politik Bahasa Nasional 2. Jakarta: Pusat Pembinaan dan Pengembangan Bahasa.

Hill, J., \& Gale, T. (Eds.). (2009). Ecotourism and Environmental Sustain ability Principles and Practice. Farnham, UK: Ashgate.

Rais, J. dkk. (2008). Toponimi Indonesia. Jakarta: Pradnya Paramita.

Danandjaja, J. (1994). Folklor Indonesia: Ilmu Gosip, Dongeng, dan Lain-lain. Jakarta: Pustaka Utama Grafiti.

Kostanski, L. (2011). Toponymic dependence research and its possible contribution to the field of place branding. Place Branding and Public Diplomacy, 7 (1), 9-22.

Lembaga Kebudayaan, Universitas Pasundan. (1989). Bahasa Sunda di Kabupaten Pekalongan, Banyumas, dan Cilacap, Propinsi DT. I Jawa Tengah. Laporan Penelitian. Bandung.
Kulsum, U. dkk. (2008). Nama Tempat di Kota Bandung yang Berhubungan dengan Air: Tinjauan Antropolinguistik. Bandung: Balai Bahasa.

Muhsin, M. (2012). Pajajaran dan Siliwangi dalam Lirik Tembang Sunda. Panggung, 22 (2), 139-146.

Pedersen, A. (2017). “The Transmission of Toponyms in Language Shift Societes" dalam Terhi Ainiala dan JanOla Ostman (Ed.). Socio-onomastics: The Pragmatics of Names. Amsterdam/Philadelphia: John Benjamins Publishsing Company.

Radding, L. \& Western, J. (2010). Linguistics, Geography and Toponyms. The Geograficals Review, 100 (3), 394-412.

Sobarna, C. (1993). "Makna Nama: Cara Berpikir Masyarakat Sunda" dalam Robert Sibarani dan Henry Guntur Tarigan (Ed.). Makna Nama dalam Bahasa Nusantara: Sebuah Kajian Antropolinguistik. Bandung: Bumi Siliwangi. (2010). Bahasa Sunda di Desa Dermaji, Kecamatan Lumbir, Kabupaten Banyumas, Jawa Tengah. Laporan Penelitian. Fakultas Sastra, Universitas Padjadjaran Bandung.

. (2013). Ancaman Kepunahan Bahasa di Daerah Enklave: Kasus Bahasa Sunda di Desa Dermaji, Jawa Tengah. Makalah Seminar Nasional Bahasa Ibu VI. Universitas Udayana, 22-13 Februari 2013. Denpasar, Bali. ---. (2015). Kearifan Lokal Masyarakat Sunda dalam Pelestarian Lingkungan dan Ekowisata (Kajian Toponimi Jabar Selatan). Laporan Penelitian Academic Leadership Grant. Universitas Padjadjaran, Bandung. (2016). Nama Tempat di Wilayah Jabar Selatan: Sebuah Representasi Kearifan Lokal Kesadaran Ekologis Masyarakat Sunda. Prosiding Seminar Nasional Toponimi "Toponimi dalam Perspektif Ilmu Budaya" 
Depok: FIB, UI.

Soemaryatmi. (2012). Dampak Akulturasi Budaya pada Kesenian Rakyat. Panggung 22 (1), 25-36.

Sudaryanto. (1993). Metode dan Aneka Teknik Analisis Bahasa Pengantar Penelitian Waha- na Kebudayaan secara Linguistis. Yogyakarta: Duta Wacana University Press. Sudaryat., Y. (2005). Pemakaian Bahasa Sunda dalam Sistem Toponimi Nama Daerah di Jawa Barat. Bandung: Jurusan Pendidikan Bahasa Daerah FPBS UPI. 